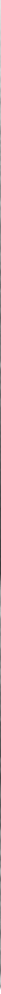

Denver Zoological Gardens

\title{
Capybara Ranching for Amazonia?
}

\author{
Daniel E. Vasey
}

Cattle ranching for beef is slowly spreading in the Amazonian floodplains and could lead to a serious loss of wildlife habitats. The author suggests that the indigenous capybara could be a satisfactory alternative for ranching, and one that would not require swamps or areas that are flooded seasonally to be drained.

The South American capybara Hydrochoerus hydrochaeris is the world's largest rodent, weighing up to sixty kilograms in captivity. It is semi-aquatic, feeding on grass, aquatic vegetation and some browse. In Amazonia, it principally occupies the floodplains which hold most of that basin's fertile soils and also have the greatest potential for agricultural development, including cattle ranching. Capybaras are hunted for food, and Amerindians sometimes rear orphaned young. In captivity they are tractable; one is even reported to have been used by a blind man as a guide animal. ${ }^{1}$ In zoos, they present no special management problems, and breeding and longevity records are good. But no specific data matching dietary intake to growth have been published. ${ }^{2}$ The Denver, Colorado, Zoological Gardens allowed me to monitor the diet of their capybaras, which were not on exhibit during the observations, and also made available the results of periodic weighings. Some significant results were obtained, even though the experimental rigour of a laboratory was not possible.

At the beginning of the observations the zoo had a mated pair of adults and 
one young of each sex out of a litter of five born on 11 November 1973. The young were separated from their parents, and from 7-12 July 1974 the net food intakes of both groups were recorded. The daily feeding schedule was one that the keepers had followed over the previous month, and the only leftovers I saw were small quantities of hay.

The combined daily intake of the two young varied little, averaging 260 grams total protein and 4400 calories, from carrots, apples, lettuce and spinach (together 19 per cent of calorie intake), Purina monkey chow (71 per cent) and lucerne ( 10 per cent). The two young together weighed 2, 60 and 82 kilograms, at birth, 265 and 316 days respectively. Linear regression of the three weighings estimates an average daily combined gain of 238 grams. Including the weight at 122 days of a female litter-mate ( 20 kilograms) does not significantly alter the slope of the regression curve, and no other weights were available for this litter after birth. Assuming this rate of gain at the time of the feeding trials, 1.1 grams of protein and 18 calories were consumed for every gram of weight gain. A faecal analysis at the time of the feeding trials indicated that the lucerne was not being well digested, ${ }^{3}$ and the accelerated weight gain between the second and third weighings, when the animals were outside on pasture, suggests that at the time of the trials the young were underfed, which would result in a lowered conversion efficiency.

On 21 December 1975 a litter of five, all males, was born, and food intakes were recorded from 2-9 February 1975. The young were housed with their mother and their intake was estimated by subtracting the mother's maintenance ration, established earlier, from the group's total intake. The overall method and the relative proportions of food were similar to those in the previous experiment, except that meadow hay was substituted for lucerne, Purina dog chow for about half the monkey chow, and enough was fed so that some pellets and hay were left over each day. These were air-dried, weighed and subtracted from the consumption figures. With the adjustments for the mother's maintenance ration included, the daily intake averaged $580-240=340$ grams total protein and $10,800-4000=6800$ calories. Faecal analysis indicated good utilisation of the meadow hay. ${ }^{4}$ At birth these five young together weighed less than five kilograms; at 58 days they weighed 43 kilograms, so that they gained an average of 670 grams a day. At this rate, 0.5 grams of protein and 10 calories were consumed per gram of weight gain at the time of the trials. The improvement over the conversion efficiency of the previous year's litter could be attributed to better feeding, the younger age at the time of the test, or experimental and statistical error. Actually, since the feeding trial ended only nine days before the weighing, average consumption for the period would, if anything, be overestimated, and efficiency thereby underestimated.

\section{Discussion}

The table opposite compares the performance of the test capybaras to that of beef cattle under optimal conditions. The results probably underestimate the ecological advantages of capybaras over beef cattle, especially in the Amazonian environment. The protein-to-calorie ratio of the capybara diet is rather high for grazing animals, and it is likely that excess protein was being burned for energy. Capybaras bear four to eight young per year, and thus fewer non-productive adults would be maintained than with cattle. In the floodplain environment, capybaras, unlike cattle, can utilise aquatic vegetation.

The outcome indicates that more rigorous experiments should be 


\section{Comparative Conversion Efficiencies of Test Capybaras and Dry-Lot Finished Steer Calves}

$\begin{array}{lccc}\begin{array}{l}\text { Consumption per } \\ \text { gram weight gain }\end{array} & \begin{array}{c}\text { Capybaras- } \\ 1973 \text { litter }\end{array} & \begin{array}{c}\text { Capybaras- } \\ 1974 \text { litter }\end{array} & \begin{array}{c}\text { Steer Calves- } \\ 200-450 \text { kilograms }\end{array} \\ \text { Grams total protein } & 1.1 & 0.5 & 1.15 \\ \text { Calories } & 18 & 10 & 26.2\end{array}$

performed, preferably under Amazonian conditions. However, even if this were done and the results verified or improved, on the results of the experiment capybaras are not likely to become an alternative to cattle in the near future. One difficulty is that there is no export market, and even within Amazonia, regard for the meat varies greatly from place to place. Fortunately, there is no immediate large-scale threat to the environment from cattle ranching, but when the world becomes hungry for meat Amazonian cattle ranchers might start to drain wetlands and clear more marginal areas, and then a market might be developed for capybara meat.

Capybara ranching would not only help to preserve the species but would partly safeguard others by reducing the need for environmental modification. Preserving natural areas would be a separate concern, since there would still be pressure for forest clearance and possibly pasture improvement, but capybara ranching would not require swamps or seasonally flooded areas to be drained as intensive cattle ranching does. It is the annual floods that give these soils their fertility, and preserving the flooded areas can keep down the use of artificial fertilisers with their resulting run-off into the streams. Further research might show other ways in which the capybara's natural adaptation to the environment would have less impact than that of cattle on the habitats of other species.

To sum up: in its native environment the capybara is a promising alternative to beef cattle, but further investigation is needed to determine its potential. Other Amazonian herbivores, such as the tapir and other rodents-pacas and agoutis - are worth investigating as well, notably in the areas away from the river, where cattle ranching tends to result in serious soil depletion.

\section{Acknowledgments}

I wish to thank Assistant Director Paul N. Linger, who first offered the Denver Zoological Garden's cooperation, Edward C. Schmitt, Curator, and the keepers. Without Keeper William Losberg's interest and cooperation, the work would have been far more difficult.

\section{References}

1. SANDERSON, I. T. 1965. Living treasure. Pyramid Publications.

2. PIRIE, N. W. 1967. Orthodox and unorthodox methods of meeting world food needs. Scientific American 216 22, 27-35.

3. Agricultural Consultants, Inc., Brighton, Colorado.

4. Ibid.

5. AGRICULTURAL RESEARCH SERVICE. 1973. Finishing beef cattle. U.S. Department of Agriculture.

Dr Daniel E. Vasey, Assistant Professor of Anthropology, Metropolitan State College, Denver, Colorado, USA. 